\title{
Socio-hydrology and the science-policy interface: a case study of the Saskatchewan River basin
}

\author{
P. Gober ${ }^{1,2}$ and H. S. Wheater ${ }^{3}$ \\ ${ }^{1}$ Johnson-Shoyama Graduate School of Public Policy, 101 Diefenbaker Place, University of Saskatchewan, \\ Saskatoon, SK S7N 5B8, Canada \\ ${ }^{2}$ Research Scientist, School of Geographical Sciences and Urban Planning, Arizona State University, \\ Tempe, AZ 85287-5302, USA \\ ${ }^{3}$ Canada Excellence Research Chair, Global Institute for Water Security, National Hydrology Research Centre, \\ 11 Innovation Boulevard, Saskatoon, SK S7N 3H5, Canada
}

Correspondence to: P. Gober (patricia.gober@usask.ca) and H. S. Wheater (howard.wheater@ usask.ca)

Received: 12 April 2013 - Published in Hydrol. Earth Syst. Sci. Discuss.: 29 May 2013

Revised: 31 January 2014 - Accepted: 27 February 2014 - Published: 11 April 2014

\begin{abstract}
While there is a popular perception that Canada is a water-rich country, the Saskatchewan River basin (SRB) in Western Canada exemplifies the multiple threats to water security seen worldwide. It is Canada's major food-producing region and home to globally significant natural resource development. The SRB faces current water challenges stemming from (1) a series of extreme events, including major flood and drought events since the turn of the 21st century, (2) full allocation of existing water resources in parts of the basin, (3) rapid population growth and economic development, (4) increasing pollution, and (5) fragmented and overlapping governance that includes the provinces of Alberta, Saskatchewan, and Manitoba, various Federal and First Nations responsibilities, and international boundaries. The interplay of these factors has increased competition for water across economic sectors and among provinces, between upstream and downstream users, between environmental flows and human needs, and among people who hold different values about the meaning, ownership, and use of water. These current challenges are set in a context of significant environmental and societal change, including widespread land modification, rapid urbanization, resource exploitation, climate warming, and deep uncertainties about future water supplies. We use Sivapalan et al.'s (2012) framework of sociohydrology to argue that the SRB's water security challenges are symptoms of dynamic and complex water systems approaching critical thresholds and tipping points. To Sivapalan et al.'s (2012) emphasis on water cycle dynamics, we add the
\end{abstract}

need for governance mechanisms to manage emergent systems and translational science to link science and policy to the socio-hydrology agenda.

\section{Introduction}

In a recent article in Hydrological Processes, Sivapalan et al. (2012) called for a new science of water that treats humans and their activities as endogenous features of the water cycle, interacting with the system through water consumption for their personal needs, food, and energy, and through pollution, policies, markets, and technologies. We examine the Saskatchewan River basin (SRB) in Western Canada from a socio-hydrological perspective: first by describing its geographic context in both human and biophysical terms, then by outlining the complex challenges to water security linking human activities and natural systems, and finally, by highlighting the importance of anticipatory governance and evidence-based decision-making for rapidly changing water systems.

\section{Overview of the SRB}

The SRB (Fig. 1) covers $336000 \mathrm{~km}^{2}$, encompassing a large portion of Western Canada, and is one of the world's larger river systems. The Canadian Rocky Mountains are the dominant sources of river flow, providing some $80 \%$ of runoff 


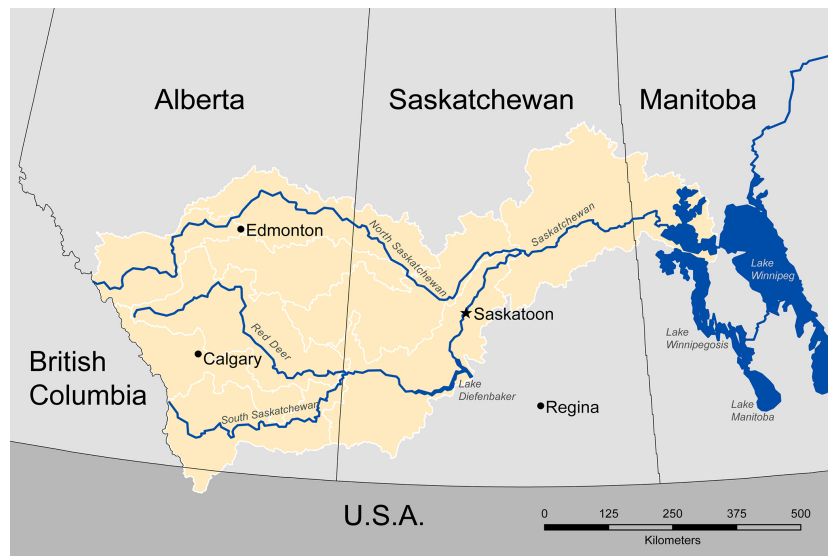

Fig. 1. Saskatchewan River basin.

(Pomeroy et al., 2005); the river's two major tributaries flow east from the continental divide. The South Saskatchewan River (SSR) passes through the Canadian prairies, a major agricultural region with high natural climatic and hydrological variability (Fig. 2). The North Saskatchewan River (NSR) drains prairie landscapes and boreal forest. The latter are an important global ecosystem and represent $35 \%$ of Canada's total land area (Natural Resources Canada, 2009). After the confluence of these two major tributaries, the river passes through one of the world's largest inland deltas, marking the downstream limit of the SRB catchment, and enters Lake Winnipeg, the world's 11th largest lake by surface area, ultimately discharging its waters into the Hudson Bay via the Nelson River (Partners for the Saskatchewan River basin, 2009; Toth et al., 2009).

The SRB is facing rapid environmental change. A warming climate is causing Rocky Mountain glaciers to retreat, changing the rain/snow balance and the processes of snow accumulation and melt, and hence influencing the magnitude and timing of river flows (Demuth and Pietroniro, 2003; Comeau et al., 2009; Moore et al., 2009; Marshall et al, 2011). Changing climate is also manifest in a mountain pine beetle infestation which has caused widespread devastation of forests in the province of British Columbia and is moving eastward into the SRB (Natural Resources Canada, 2012). In the prairie portion of the SRB, spring snowmelt is now occurring 2 to 3 weeks earlier than it did in the 1950s (Bonsal and Prowse, 2003). The changing climate brings the prospect of new extreme conditions in the form of droughts and floods, though Bonsal et al. (2012) point to evidence of extreme drought in the region's paleorecord, noting that "observed twentieth century droughts were relatively mild when compared to pre-settlement on the prairies, but these periods are likely to return (and even worsen) during this century." New patterns of extremes stress society's capacity to adapt quickly enough with new infrastructure, institutions, building codes, insurance rates, early warning systems, and emergency management procedures (Karl et al., 2008).

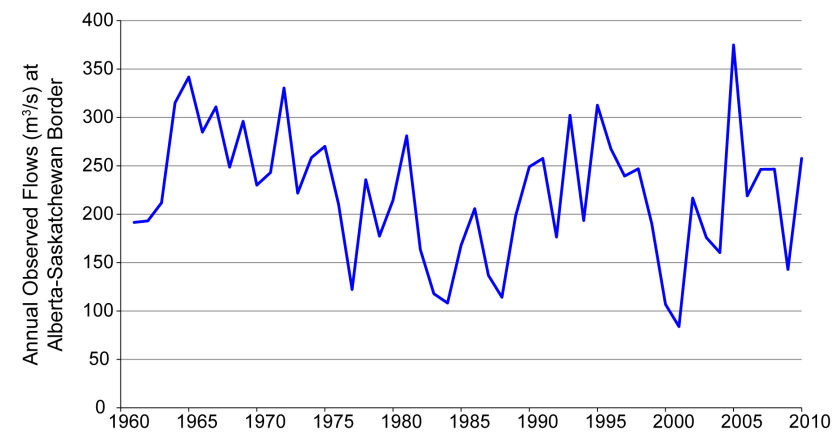

Fig. 2. Observed annual flows $\left(\mathrm{m}^{3} \mathrm{~s}^{-1}\right)$ at the AlbertaSaskatchewan Border, 1961-2010 (Alberta Environment and Environment Canada).

Residents of the Canadian prairies have always lived with extremes; they are in fact a defining feature of prairie life, history, and culture. The Palliser expedition of 18571860 observed drought conditions in the "Palliser Triangle" and declared it unsuitable for agricultural development (Marchildon, 2009; Toth et al., 2009), though later developments saw the Palliser Triangle become a major Canadian agricultural zone. The region experienced devastating drought conditions during the Dust Bowl years of the 1930s; wheat farmers flocked to cities for work; and images of large dust storms, rolling mounds of Russian thistles, and destitute prairie farmers filled newspapers across Canada (Encyclopedia of Saskatchewan, 2012). Recent examples of natural extremes included a major drought from 1999 to 2004, with a CAD 3.0 billion drop in Western Canadian agricultural production in 2001-2002. The economic impacts in this paragraph are reported in CAD. (see e.g., Wheaton et al., 2008). Extensive flooding in 2011 caused widespread damage across the prairies; many communities experienced flooding, with some 40 roads under water in Saskatchewan alone, and costs in Manitoba were reported to exceed CAD 800 million (CBC News, 2011). Most recently, in June 2013, flooding in Alberta caused 4 deaths and the evacuation of 100000 people from the city of Calgary (The Economist, 2013), with direct costs estimated as exceeding CAD 5 billion (CBC News, 2013).

Groundwater use in the SRB is curbed by the limited extent of large aquifers and low rates of recharge (Toth et al., 2009). Total groundwater use is less than $1 \mathrm{~mm}$ per year, averaged over the area of the basin. Nevertheless, groundwater resources are sufficient to provide water supplies for numerous individual houses and many small towns, where reliable surface water supplies are not available. Much of the prairies would be uninhabitable if it were not for water from wells. However, the potential of using groundwater for large-scale irrigation is minimal due to the low yields of wells and the unsuitable chemistry of groundwater. In principle, groundwater supplies represent a critical degree of water security, because they are relatively insensitive to drought. In practice, 
sustainable yield remains uncertain because recharge processes are largely unquantified (Peach, 2013).

The prairies are Canada's major food-growing region. Dryland agriculture, depending on precipitation to supply moisture to crops and pastures, is the dominant food production method. However, early European settlement recognized that irrigation could enhance productivity, and major waterworks were developed in southern Alberta. Today, the region is responsible for approximately $75 \%$ of Canada's irrigated agriculture (Agriculture and Agri-Food Canada, 2011). Diversions for irrigated agriculture account for $82 \%$ of consumptive water use in the SRB (Martz et al., 2007).

In addition to irrigation use, the large-scale development of the river includes dams for hydropower, water supply for industry and urban centers, and flood relief. The largest of these is the $225 \mathrm{~km}$-long Lake Diefenbaker multipurpose reservoir in Saskatchewan which stores 9.4 billion $\mathrm{m}^{3}$ of water (Saskatchewan Water Security Agency, 2014). Lake Diefenbaker's Gardiner Dam has heavily modified conditions downstream (Fig. 3), with additional effects due to peak power generation at the E. B. Campbell Dam and Electrical Power Station further north. Infrastructure also affects flow regimes downstream in the Cumberland Delta, one of Canada's richest regions for its abundant and diverse wildlife. In addition to the upstream water withdrawals and river regulation, removal of sediment outflow by impoundment has enlarged channels downstream and reduced sediment-borne nutrients to the delta's ecosystem. Suppression of annual discharge peaks has reduced the frequency of overbank flooding and, consequently, the frequency at which water and nutrients are replenished in the delta wetlands. Changes in the ecosystem are of profound concern to First Nations and Métis communities who depend on the delta for fishing, hunting, trapping, and subsistence agriculture for their livelihoods.

Inter-provincial flows on the Saskatchewan River are governed by the Prairie Provinces Water Board Master Agreement on Apportionment, approved in 1969. In simple terms, the Master Agreement requires the Province of Alberta to pass $50 \%$ of the river's annual natural flow to Saskatchewan, which in turn is required to pass $50 \%$ of that flow to Manitoba plus $50 \%$ of flow arising in Saskatchewan (Prairie Provinces Water Board, 2009). While concerns have been expressed that under extreme drought in Alberta may have difficulty maintaining its responsibilities to senior license holders (some of which predate the agreement), the agreement has so far proved a robust framework that encourages cooperative water management and sharing of information.

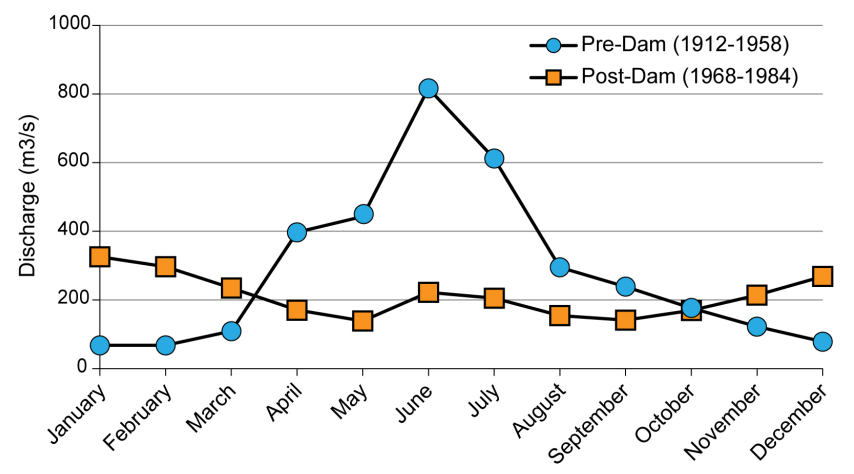

Fig. 3. Annual hydrograph of the SSR at Saskatoon pre- and postconstruction of the Lake Diefenbaker Reservoir (Water Survey of Canada).

\section{Challenges to water security}

\subsection{Environmental change}

Increasing evidence indicates that the environmental systems that support large-scale urbanization and commercial agriculture (grains and livestock), and produce oil and gas to power the USA and China, are being altered by anthropogenic climate change. Nowhere is this process more apparent than in the Canadian Rockies and foothills region in Alberta which provide about $77 \%$ of the Saskatchewan River's flows (Toth et al., 2009). In a typical year, the accumulation of winter snow leads to snowmelt in spring and early summer which generates a characteristic early summer peak in the annual hydrograph. Later in the year, low flows are maintained by glacier melt, rainfall, and slow subsurface drainage processes (Toth et al., 2009). In recent years, these processes have been changing in a manner typical of a warming climate. Glaciers still provide important low flow contributions to the North Saskatchewan River basin (NSRB), but the southern glaciers have retreated to the point of insignificant runoff generation. Data from the Marmot Creek Experimental Basin in the Rocky Mountains have shown that over the last 50 years, winter minimum temperatures have increased by $5^{\circ} \mathrm{C}$, and that these changes are associated with changing patterns of distribution between snowfall and rainfall, smaller snowpacks, and earlier spring snowmelt (Harder and Pomeroy, 2013).

The prairie landscape portion of the South Saskatchewan River basin (SSRB) has a different hydrological pattern and will be affected differently by climate change. This climate is semi-arid, and the topography is gently rolling or flat; the recently glaciated landscape is dominated by internal drainage basins and many hundreds of thousands of small lakes and wetlands which provide important habitats for wildlife (Fang et al., 2007). Less than $50 \%$ of the prairie area normally connects to a major river system (Toth et al., 2009) and flow contributions are typically small; average runoff per unit area 
from the prairie uplands is only about $10 \%$ of the runoff from the mountain slopes. The landscape is dominated by snow and ice for 4 to 6 months of the year. Future climate projections indicate a warming and wetting, with the greatest change in winter, though recent results show significant variability between models (Mearns et al., 2012; Khaliq et al., 2014). Some estimates project a decrease in summer precipitation for Alberta and Saskatchewan by 2081-2100, although projected changes to precipitation, and in particular hydrological extremes, remain highly uncertain (Wheater, 2002, 2009; Khaliq et al., 2014). Also uncertain are the effects on streamflow of increasing precipitation and increasing evaporation due to a warmer climate. Recent hydrological simulations for the SRB reveal changes in the annual streamflow ranging from an $8 \%$ increase to a $22 \%$ decrease (Pomeroy et al., 2009). Small-scale hydrological models for prairie streams suggest a $24 \%$ increase in spring runoff by 2050 followed by a $37 \%$ decrease by 2080 as the winter snow cover becomes discontinuous (Pomeroy et al., 2009).

\subsection{Population growth and economic development}

Canada's prairie provinces, especially Alberta, are in the throes of large-scale population and economic growth, and increased prosperity, with profound consequences for land modification and water management. Alberta's historical development was based on agriculture and cattle production, but more recently, natural resource exploitation, including petroleum development and tourism, has been added to the mix. The Calgary-Edmonton Corridor is the most urbanized region in the province and one of the densest and fastest growing in Canada. In 2012, Alberta's population was 3.8 million; almost $65 \%$ larger than its size in 1980 (Centre for the Study of Living Standards, 2012). Growth in per capita gross domestic product in Alberta vastly outstripped the Canadian average after 1980, except for a temporary downturn during the global recession of 2007-2008 (Centre for the Study of Living Standards, 2012) (Fig. 4). Alberta was Canada's fastest growing province between 2006 and 2011, with a 5-year population growth rate of $10.6 \%$ (Statistics Canada, 2013).

Rapid growth, urbanization, agricultural intensification, oil and gas exploitation, and allocation of more than $100 \%$ of the flow of some sub-basins increased competition among licensed users, reduced water quality, and degraded riparian ecosystems. Schindler and Donahue (2006) warned of "an impending water crisis in Canada's western prairie provinces" involving the interaction of these effects. A severe drought in 2001-2002 revealed vulnerabilities in Alberta's water system as farmers were required to cut back water use and cattle producers reduced their herds or hauled stock water (Wandal et al., 2009). The province was unable to meet the requirements of all of its water licensees, and came close to being unable to deliver $50 \%$ of the river's natural flow to Saskatchewan, as stipulated in the Prairie Provinces

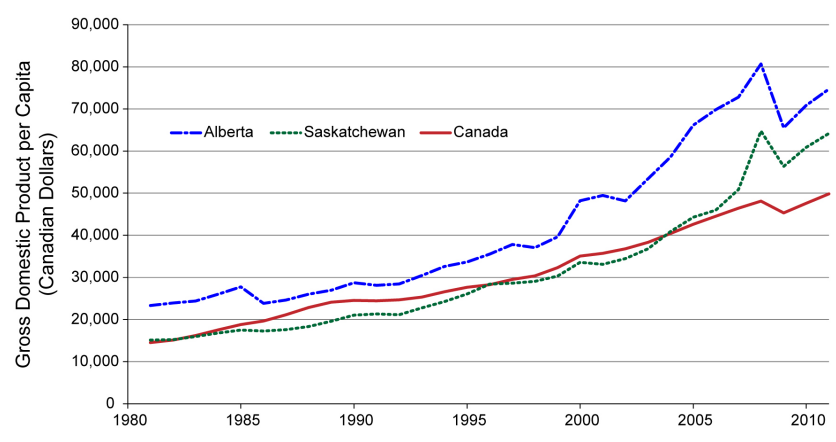

Fig. 4. GDP in Canada, Saskatchewan, and Alberta: 1990-2010 (Centre for the Study of Living Standards, 2012.

Master Agreement. Acknowledging that the water system was tapped out, Alberta Environment temporarily closed three sub-basins (Oldman, Bow, and South Saskatchewan) to new water licenses in 2003 (Alberta Environment, 2003a). At the local level, some senior licensees shared their apportionments with junior licensees to maintain the economic viability and social structure of fragile rural communities. From a governance perspective, Diaz and Warren (2012) have interpreted these informal agreements as a response to inflexible senior governance and as a sign of community resilience in the face of climatic uncertainty.

Another symptom of increasing vulnerability and approaching a critical threshold is the decline in water quality. Phosphorous loadings exceeded Alberta's official chronic guideline of $0.5 \mathrm{mg} \mathrm{L}^{-1}$ (Alberta Environment, 1999) for most of the SSR downstream from the Rockies, and the situation has become dire over time (Fig. 5). Data from 18 monitoring stations between 1973 and 2007 show especially high phosphorous levels downstream from Alberta's intensive agricultural areas and feedlots but much lower levels downstream from Lake Diefenbaker in Saskatchewan. Data from the period 2011-2012 indicate that $90 \%$ of the incoming phosphorous is retained in Lake Diefenbaker where eutrophication is of increasing concern (Hecker et al., 2012). The Saskatchewan River ultimately discharges to Lake Winnipeg, which receives a major load of nutrients from the USCanadian trans-boundary Red River. In 2007, Lake Winnipeg had an algal bloom of some $15000 \mathrm{~km}^{2}$ in area (Kling et al., 2011).

Alberta used simulation experiments with its Water Resources Management Model (WRMM) to assess the state of its water supplies, asking whether it would be possible for current resources to support agricultural expansion and assure ecosystem health under different environmental flow conditions. The model considered 10 and $20 \%$ increases in agricultural acreage over current allocations and used instream objectives (IOs) attached to current licenses and instream flow needs (IFNs) to represent flows adequate to protect water quality, fish habitat, riparian ecosystems, and channel maintenance. Model runs produced sobering results 


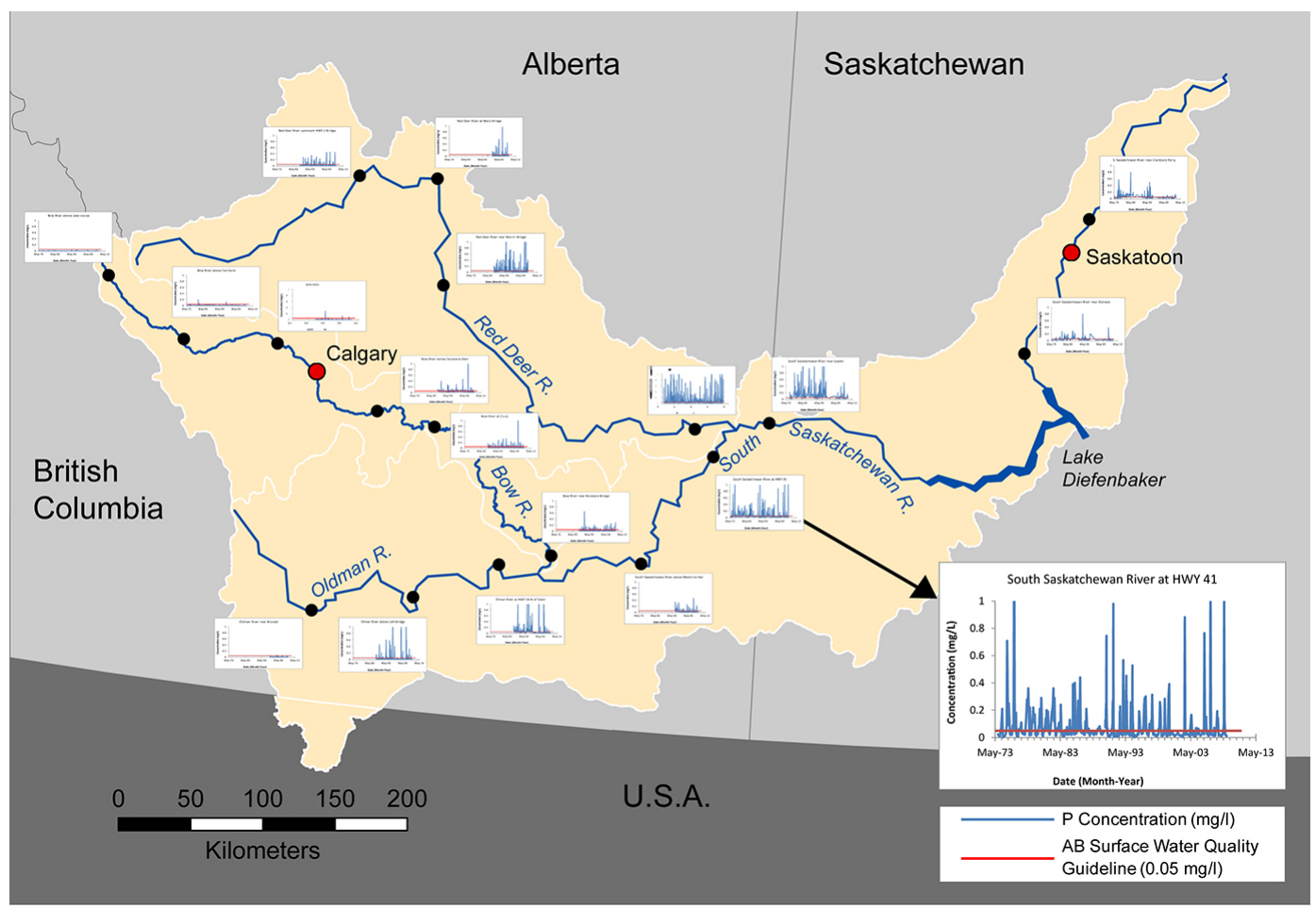

Fig. 5. Total phosphorous concentration (1973-2009) in Alberta and Saskatchewan (Federal data through the Prairie Provinces Water Board, Alberta data from Alberta Environment - River Network Station Water Quality Data, accessed online through http://environment.alberta.ca/ 01288.html, Saskatchewan data from Saskatchewan Ministry of Environment).

(Alberta Environment, 2003b). The IOs were very low compared to INFs in most years. Although it would be possible to expand irrigated acreage and improve environmental flows under average conditions, it would not be possible to support future growth and protect the environment in dry years. While growth can be accommodated in average years, drought forces the system into deficit. Thus, governance and policy need to reflect allocation strategies in dry years - how shortages would be allocated across existing license holders. Ideal IFNs could sometimes be achieved, but infrequently. Agricultural expansion would result in deficits for junior licensees under drought conditions, and environmental flows could be augmented, but only at the expense of junior licensees. As noted above, most of the three subbasins were permanently closed to new license applications. In 2003, Alberta authorized a water planning process with goals to improve management and administration of allocations, develop markets to transfer water to higher-value development, and encourage water conservation. From that planning process there emerged an evolving strategy for sustainability called Water for Life that acknowledged that new development will occur through conservation, reuse, and transfer (Alberta Environment, 2012). The Alberta Water Exchange, Inc. was established to acquire licenses from those who have excess capacity and bring licenses into good standing through reconstruction and proper operation of water works. The Alberta Water Exchange enables the transfer of licenses to new users and allows new development to occur despite full allocation (Alberta Water Exchange, 2012). In a recent survey of stakeholders in the SRB, land management issues were listed by $40 \%$ of Alberta respondents as the single highest priority for water management, reflecting the inherent trade-offs and demand-side issues that accompany rapid development in a fully allocated system (Gober et al., 2014).

Saskatchewan's economic growth spurt was more recent (Fig. 4), but followed Alberta's trajectory with rapid growth and economic development, pressure for more water licenses, water quality issues, and emphasis on supply- over demand-side management. Saskatchewan's development is also rooted in resource development, including food production (livestock and wheat), potash and uranium mining, and oil and gas extraction. The province (approximately the size of France) has slightly more than 1 million residents (as of 2011), and in most years, uses only a small portion of river flows; the assumption has been that adequate water supplies are available to support future growth. In 2012, the Saskatchewan Ministry of Agriculture published a report called "Lake Diefenbaker's Unfinished Business" outlining the potential to irrigate up to 500000 additional acres (from today's 109000 ), using only $17 \%$ of current flows under normal conditions (Saskatchewan Ministry of Agriculture, 
2012). The pressure to expand irrigated agricultural production raises important questions about whether there will be enough water during drought years; whether climate change will alter streamflows and future water supplies; what agricultural expansion means for dam management, river and lake levels, recreational uses, hydroelectric power generation, and environmental flows; and what other opportunities will be foregone as full allocation is approached. These issues are symptomatic of the changing public conversation about water as human and natural stressors begin to threaten both quantity and quality, and difficult choices that need to be made about allocation, land use regulation, water for the environment, and competing development paths.

The Government of Saskatchewan recently formed a Water Security Agency and released a 25-year Water Security Plan (Saskatchewan Water Security Agency, 2013) to address the need for sustainable supplies, water quality, ecosystem protection, hazards mitigation, improved governance and increased public engagement. Sustainable development is to be achieved through more efficient water use, new water supply infrastructure, and reassessment of current allocations. Unlike Alberta where the legal framework adheres to firstin-time, first-in-right water apportionment, Saskatchewan's water framework provides the Water Security Agency with greater flexibility to adjust future allocations and adapt to changing environmental and societal conditions. However, this flexibility leaves some users uncertain about how deficits will be handled during future drought conditions.

\subsection{Governance}

In a prosperous and highly educated country like Canada, the challenges of climate change and rapid development should be manageable through foresight and coordination of water resource systems. Public attitudes in Canada acknowledge the reality of climate change and the vital role of governmental institutions in addressing it. In 2011, $80 \%$ of Canadians (compared to $58 \%$ of Americans) believed that there is solid evidence that earth's temperatures have been warming (Lachapelle et al., 2012). A similarly higher proportion of the Canadian population believed that governments at all levels: federal (65\% versus $43 \%$ ), provincial and state (53\% versus $35 \%$ ) and local (42\% versus $29 \%$ ) have a role to play in taking actions to reduce climate warming. Even then, however, many parts of Canada, including the SRB, face an uphill battle to anticipate and adapt to climate change, in part, because fragmented and rigid governance systems prevent coordinated and proactive response.

Fragmentation begins with the fact that watershed boundaries rarely coincide with political boundaries; myriad levels of government have overlapping, and sometimes conflicting, responsibilities for water management. The Constitution Act of 1930 between Canada and each of its western provinces passed responsibility for land and resources, including water, to the provinces (Partners for the Saskatchewan River Basin,
2009). As such, the provinces are responsible for infrastructure, flood forecasting, drinking water standards, water quality management, source water protection, water licenses, and fisheries regulation. The federal government has responsibility for trans-boundary issues, management of fish habitat, navigation and shipping, regulation of toxic substances, and First Nations lands. Obvious conflicts and gaps arise in the management of a multi-provincial water system that includes a large number of small, geographically dispersed First Nations reserves. Water quality on First Nations lands is the responsibility of the federal government, but protection of source waters lies at the provincial or local levels through groundwater-surface water interactions, land use management, community development, and collaborative watershed partnerships (Timmer et al., 2007). Boiled water advisories signal that community drinking water supplies are contaminated by pathogens, and there is a need to boil water before consuming it. As of 31 October 2013, there were 118 First Nations communities across Canada under a Drinking Water Advisory (Health Canada, 2013). According to Patrick (2011), they reflect the lack of coordination between local and national water authorities and an unfortunate disconnection between land and water governance.

Growing evidence from the policy sciences suggests that dealing with fragmentation is not simply a matter of consolidating management into highly centralized systems, but rather better coordination of place-based, watershed-level governance. Brunner (2010) has warned of scientific bias in searching for the "one best way" to rationalize natural resources governance and preference for centralized decisionmaking. He argues that adaptation efforts are most effective when they occur at the local level, incorporate a wide range of views in policy development, and find ways to use local knowledge to supplement scientific inquiry. In Western Canada, watershed advisory groups have been established to fill this vital governance role, but they are limited by the lack of legislative authority, uncertain budgets, and over-reliance on volunteers for planning and management (Hulbert et al., 2009). The 2001-2002 drought demonstrated the value of local and informal governance mechanisms as strong community spirit enforced compliance with water-saving strategies and the social cohesion of rural communities facilitated cooperative strategies to persuade senior water rights holders to share their allocations to maintain the viability of rural communities (Diaz et al., 2009; Marchildon, 2009).

Coordinated responses to new conditions are also challenged by the uncertainties associated with global climate model results and their regional downscaling. Wilby and Dessai (2010) described a "cascade of uncertainty" accompanying regional impact assessment, beginning with different views of future society, climate model results, regional impacts, and potential adaptation resources and note the difficulty of accommodating this level of uncertainty in scienceled adaptation efforts. The information systems of fragmented entities often are ill-prepared to deal with uncertain 
climate model results, how to integrate data from varying spatial scales and technical sources, and how to mesh quantitative and qualitative results with the local knowledge and experiences of different operational and policy staffs. Prior research has demonstrated that policymakers view uncertainty as a constraint which may cause them to avoid solutions that employ uncertain information, exhibit bias toward initial solutions, undervalue negative or contrary evidence (Cohen and Wallsten, 1992; Reece and Mathews, 1993). Decisionmaking under uncertainty (DMUU) strategies are designed to manage, rather than reduce, uncertainty. They include exploratory modeling, scenario planning, robust decisionmaking, and anticipatory governance (Lempert et al., 2003; Folke et al., 2005; Quay, 2010; Gober et al., 2010; Gober, 2013). Anticipatory governance focuses on proactive solutions to environmental risk, rather than reactive emergency management strategies. Adaptation for prairie water systems can include building new and retrofitting old infrastructure, adjusting operational procedures, re-evaluating flood insurance programs, changing building codes, drafting new floodplain maps, changing cropping strategies, upgrading emergency warning and preparedness, coordinating governance, investing in innovative technology, and creating new knowledge about water conservation and reuse. These strategies are critical to preventing water systems from passing critical thresholds and to managing change as systems transition from one state to another.

\section{Socio-hydrology and the science-policy interface}

Sivapalan et al. (2012) have used the term socio-hydrology to describe the study of the "co-evolution of human-natural coupled systems." They argue that it is not possible to predict water cycle dynamics over decadal or longer time periods without considering interactions and feedbacks among natural and human components of the water system. The combination of human conditions (e.g., urbanization, economic growth, and inadequate governance) and natural forces (climate change, droughts, and floods) has both triggered crisis and opened policy windows in the SRB. The 2001-2002 drought in a fully allocated water system led to devastating economic loss in rural communities, but it also opened a policy window in Alberta where allocations were capped through the province's Water for Life strategy. A recent (June 2013) flood in Calgary, dubbed the "costliest natural disaster in Canada's history" with damage estimates exceeding CAD 5 billion, had a similar impact on policy. Alberta Premier Alison Redford responded not only in the traditional fashion of providing relief to those who experienced loss, but also in a more proactive, anticipatory way by mandating increased control of land use in high-risk areas and denying future flood insurance coverage to property owners who seek to rebuild in the floodplain (Calgary Herald, 2013). The jury is still out on the future of Lake Diefenbaker as to whether new inter-provincial water quality standards will be set and enforced in time to prevent eutrophication or will business-asusual regulatory practices enable accumulation of phosphorous levels in lake sediments, with predictable consequences for water treatment, recreational activities, and ecosystem functions.

As complex and dynamic water systems approach critical thresholds and tipping points, it is easy to advocate for proactive, large-scale, and top-down policy solutions. The policy literature suggests, however, that most water problems are resistant to fundamental change, and at best produce incremental results. Huitema and Meijerink (2010) note that, while it may not always be possible to implement centrally controlled policies for emergent systems, it may be possible to be better prepared and navigate from point to point through social processes that exploit windows of opportunity, use multiple venues (government, business, and the media) for debate and decision-making, and deploy knowledge networks of interested parties working for change. As mentioned earlier, the groundwork for change has been laid for these processes in the SRB by a network of watershed steward organizations that were created to develop source water protection plans, but their capacity for action is limited by lack of decisionmaking authority, permanent staff, and stable budgets.

An expansive view of socio-hydrology also considers the so-called science-policy interface, including the social processes that link scientific knowledge to emerging networks of decision-making and governance. Traditionally, the water science community adhered to what Feldman and Ingram (2009) call the "loading dock model" of decision support, assuming that scientists would prepare models, forecasts, and other products for water agencies to use for management decisions. There is increasing evidence, however, that this method is not up to the task of supporting the sorts of decision-making processes described above (National Research Council, 2007, p. 34). Reasons include inflexible decision rules, informal arrangements that prefer established and tested practices over new kinds of decision tools, organizational culture and reward structures, risk-averse and vulnerable cultural contexts, lack of meaningful interaction between scientists and decision-makers, hard-to-interpret presentation of scientific information, cascading uncertainties when climate model results are used for regional and local prediction, and user difficulty in translating probability information into action. Feldman and Ingram (2009) emphasize the potential of mutual learning among scientists and between scientists and decision-makers for more effective translation of scientific information through knowledge networks to affect water resources decision-making. 


\section{Summary and conclusions}

In sum, we have provided an overview of water system dynamics in the Saskatchewan River basin, emphasizing the view of the basin as a human-natural coupled system, highlighting the challenges of managing complex, dynamic systems through periods of transition, and arguing for a new paradigm of water science to link water scientists to new users of knowledge. Our case study of the SRB demonstrates the place-based and multi-scaled nature of sociohydrological research; the problems that can arise when the integrated water system, including human and biophysical components, are not treated holistically; the increasingly difficult choices that lie ahead for the SRB; the pressing need for coordinated and anticipatory governance; and the potential for better communication between modelers and managers to lead to more relevant water science and to its more effective use for evidence-based decision-making.

Acknowledgements. This research was supported by the Global Institute for Water Security under funding from the Canada Excellence Research Chair for Water Security and the Decision Center for a Desert City II: Urban Climate Adaptation at Arizona State University (National Science Foundation SES-0951366). Any opinions, findings and conclusions or recommendations expressed in this paper are those of the authors and do not necessarily reflect the views of the University of Saskatchewan or the National Science Foundation.

Edited by: V. Srinivasan

\section{References}

Agriculture and Agri-Food Canada: An Overview of the Canadian Agriculture and Agri-Food System, available at:http://www4.agr.gc.ca/AAFC-AAC/display-afficher.do?id= 1295963199087\&lang=eng (last access: 3 April 2013), 2011.

Alberta Environment: Surface Water Quality Guidelines for Use in Alberta, available at: http://environment.gov.ab.ca/info/library/ 5713.pdf (last access: 9 April 2013), 1999.

Alberta Environment: South Saskatchewan River Basin Water Management Plan Phase 2, Alberta Environment Publication No. 719, available at: http://www3.gov.ab.ca/env/water/regions/ssrb/pdf_ phase $2 /$ Phase $\% 202 \% 20$ Part $1 \% 20$ Modelling\%20Results $\%$ 20June $\% 2010 \% 202003 \% 20-2 \% 20$ sided \%20FINAL.pdf (last access: 3 April 2013), 2003a.

Alberta Environment: Water for Life: Alberta's Strategy for Sustainability, available at: http://environment.gov.ab.ca/info/ library/6190.pdf (last access: 19 March 2013), 2003b.

Alberta Environment: Water for Life Progress Report: December 1, 2008-March 31, 2011, available at: http://environment.gov.ab. ca/info/library/8437.pdf (last access: 19 March 2013), 2012.

Alberta Water Exchange: What we do, available at: http: //www.alberta-water-exchange.com/what-we-do/ (last access: 3 April 2013), 2012.
Bonsal, B. R. and Prowse, T. D.: Trends and variability in spring and autumn $0{ }^{\circ} \mathrm{C}$ isotherm dates over Canada, Climatic Change, 57, 341-358, 2003.

Bonsal, B. R., Aider, R., Gachon, P., and Lapp, S.: An assessment of Canadian prairie drought: Past, present, and future, Clim. Dynam., 41, 510-516, doi:10.1007/s00382-012-1422-0, 2012.

Brunner, R. D.: Adaptive governance as a reform strategy, Policy Sci., 43, 301-341, 2010.

Calgary Herald: Redford government considers insurance options, available at: http://www.calgaryherald.com/news/Redford+ government+considers+flood+insurance+options/8991400/ story.html (last access: 7 April 2014), 2013.

CBC News: Manitoba flood cost soars to $\$ 815 \mathrm{M}$, available at: www.cbc.ca/news/canada/manitoba/story/2011/ 12/14/mb-flood-cost-rising-manitoba.html (last access: 20 March 2012), 14 December 2011.

CBC News: Premier estimates flood costs to top $\$ 5$ billion, available at: http://www.cbc.ca/news/canada/calgary/ premier-estimates-alberta-flood-costs-to-top-5b-1.1355419 (last access: 18 November 2013), 20 August 2013.

Centre for the Study of Living Standards: The Human Development Index in Canada: Estimates for Canadian Provinces and Territories, 2000-2011, available at: http://www.csls.ca/reports/ csls2012-02.pdf (last access: 8 March 2013), 2012.

Cohen, B. L. and Wallsten, T. S.: The effect of constant outcome value on judgments and decision making given linguistic probabilities, J. Behav. Decis. Making., 5, 53-72, 1992.

Comeau, L. E. L., Pietroniro, A., and Demuth, M. N.: Glacier contribution to the North and South Saskatchewan Rivers, Hydrol. Process., 23, 2640-2653, 2009.

Demuth, M. N. and Pietroniro, A.: The impact of climate change on the glaciers of the Canadian Rocky Mountain eastern slopes and implications for water resource-related adaptation in the Canadian prairies, "Phase I" - Headwaters of the North Saskatchewan River Basin, Report to the Climate Change Action Fund - Prairie Adaptation Research Collaborative, PARC. Project P55, Geological Survey of Canada Open File 4322, Geological Survey of Canada, Ottawa, 2003.

Diaz, H., Kulshreshtha, S., Matlock, B., Wheaton, E., and Whitlock, V.: Community case studies of vulnerability to climate change Cabri and Stewart Valley Saskatchewan, in: A Dry Oasis: Institutional Adaptation to Climate on the Canadian Plains, edited by: Marchildon, G. P., Canadian Plains Research Center Press, Regina, Saskatchewan, Canada, 261-289, 2009.

Diaz, H. P. and Warren, J.: Defying Palliser: Stories from the Driest Region of the Canadian Prairies, University of Regina Press, Regina, Saskatchewan, Canada, 2012.

Encyclopedia of Saskatchewan: Great Depression, available at: http://esask.uregina.ca/entry/greatdepression.html (last access: 7 March 2013), 2012.

Fang, X., Minke, A., Pomeroy, J., Brown, T., Westbrook, C., Guo, X., and Guangul, S. A.: Review of Canadian prairie hydrology: Principles, Modeling and Response to Land use and Drainage Change, University of Saskatchewan Centre for Hydrology Report \#2, University of Saskatchewan, Saskatoon, Saskatchewan, Canada, 32 pp., 2007. 
Feldman, D. L. and Ingram, H. M.: Making science useful to decision makers: Climate forecasts, water management, and knowledge networks, B. Am. Meteorol. Soc., 90, 1452-1453, 2009.

Folke, C., Hahn, T., Olsson, P., and Norberg, J.: Adaptive governance of social-ecological systems, Annu. Rev. Env. Resour., 30, 441-473, 2005.

Gober, P.: Getting outside the water box: The need for new approaches to water planning and policy, Water Resour. Manage., 27, 955-957, 2013.

Gober, P., Kirkwood, C., Balling Jr., R. C., Ellis, A. W., and Detrick, S.: Water planning under climatic uncertainty in Phoenix: Why we need a new paradigm, Ann. Assoc. Am. Geogr., 100, 357372,2010

Gober, P., Strickert, G., Clark, D., Chun, S., Payton, D., and Bruce, K.: Divergent perspectives on water security: Bridging the policy debate, Prof. Geogr., doi:10.1080/00330124.2014.883960, in press, 2014.

Harder, P. and Pomeroy, J.: The impact of climate change and forest management on the hydrometeorology of a Canadian Rockies subalpine basin. Proc. Marmot Creek Research Basin workshop, Centre for Hydrology, University of Saskatchewan, available at: http://www.usask.ca/hydrology/MarmotCrkWshop2013/ PDFs/Harder.pdf (last access: 16 May 2013), 2013.

Health Canada.: Drinking Water and Wastewater, available at: http://www.hc-sc.gc.ca/fniah-spnia/promotion/public-publique/ water-eau-eng.php\#how_many (last access: 22 November 2013), 2013

Hecker, M., Khim, J. S., Giesy, J. P., Li, S.-Q., and Ryu, J.-H.: Seasonal nutrient loading and Chlorophyll $\mathrm{A}$ in a northern prairies reservoir Saskatchewan Canada. J. Water Res. Protect., 4, 180202, 2012

Huitema, D. and Meijerink, S.: Realizing water transitions: the role of policy entrepreneurs in water policy change, Ecol. Soc., 15, available at: http://www.ecologyandsociety.org/vol15 (last access: 30 January 2014), 2010.

Hulbert, M., Diaz, H., Corkal, D. R., and Warren, J.: Climate change and water governance in Saskatchewan, Canada, Int. J. Climate Change Strat. Manage., 1, 118-132, 2009.

Karl, T. R., Meehl, G. A., Miller, C. D., Hassol, S. J., Waple, A. M., and Murray, W. L. (Eds.): Why weather and climate extremes matter. Weather and Climate Extremes in a Changing Climate. Regions of Focus: North America, Hawaii, Caribbean, and U.S. Pacific Islands, Department of Commerce, NOAA's National Climatic Data Center, Washington, D.C., USA, 2008.

Khaliq, M. N., Sushama, L., Monette, A., and Wheater, H. S.: Seasonal and extreme precipitation characteristics for the watersheds of the Canadian Prairie Provinces as simulated by the NARCCAP multi-RCM ensemble, Clim. Dynam., in review, 2014.

Kling, H. J., Watson, S. B., McCullough, G. K., and Stainton, M. P.: Bloom development and phytoplankton succession in Lake Winnipeg: A comparison of historical records with recent data, Aqut. Ecosyst. Health Manage., 14, 219-224, 2011.

Lachapelle, E.,Borick, C. P., and Rabe, B.: Public attitudes toward climate science and climate policy in federal systems: Canada and the U.S. compared, Rev. Policy Res., 29, 334-355, 2012.
Lempert, R. J., Popper, S. W., and Banks, S. C.: Shaping the Next One Hundred Years: New Methods for Quantitative, Longterm Policy Analysis, RAND Corporation, Santa Monica, CA, 209 pp., 2003.

Marchildon, G. P. (Ed.): Introduction, in: A Dry Oasis: Institutional Adaptation to Climate on the Canadian Plains, Canadian Plains Research Center Press, Regina, SK, Canada, vii-xiii, 2009.

Marshall, S. J., White, E. C., Demuth, M. N., Bolch, T., Wheate, R., Menounos, B., Beedle, M. J., and Shea, J. M.: Glacier water resources on the eastern slopes of the Canadian Rocky Mountains, Can. Water Resour. J., 36, 109-134, 2011.

Martz, L., Armstrong, R., and Pietroniro, E.: The South Saskatchewan River Basin: Physical Geography, in: Climate Change and Water: SSRB Final Technical Report, edited by: Martz, L., Bruneau, J., and Rolfe, J. T., Saskatoon, Saskatchewan, Canada, 2007.

Mearns, L. O., Aritt, R., Biner, S., Bukovsky, M. S., McGinnis, S., Sain, S., Caya, D., Correia Jr., J., Flory, D., Gutowski, W., Takle, E. S., Jones, R., Leung, R., Moufouma-Okia, W., McDaniel, L., Nunes, A. M. B., Qian, Y., Roads, J., Sloan, L., and Snyder, M.: The North American Regional Climate Change Assessment Program: Overview of Phase I Results, B. Am. Meteorol. Soc., 93, 1337-1362, doi:10.1175/BAMS-D-11-00223.1, 2012.

Moore, R. D., Fleming, S. W., Menounos, B., Wheate, R., Fountain, A., Stahl, K., Holm, K., and Jakob, M.: Glacier change in western North America: influences on hydrology, geomorphic hazards and water quality, Hydrol. Process., 23, 42-61, 2009.

Natural Resources Canada: The Atlas of Canada: Boreal Forest, available at: http://atlas.nrcan.gc.ca/site/english/ learningresources/theme_modules/borealforest/index.html (last access: 20 March 2012), 2009.

Natural Resources Canada: Mountain Pine Beetle, available at: http: //cfs.nrcan.gc.ca/pages/49 (last access: 20 March 2012), 2012.

National Research Council: Evaluating Progress of the U.S. Climate Change Science Program: Methods and Preliminary Results, The National Academies Press, Washington, D.C., 2007.

Partners for the Saskatchewan River Basin: From the Mountains to the Sea: Summary of the State of the Saskatchewan River Basin, Partners for the Saskatchewan River Basin, Saskatoon, Saskatchewan, Canada, 2009.

Patrick, R. J.: Uneven access to safe drinking water for First Nations in Canada: Connecting health and place through source water protection, Health Place, 17, 386-389, 2011.

Peach, D. W.: Groundwater and Sustainability in Saskatchewan, Global Institute of Water Security Report, University of Saskatchewan, Saskatoon, SK, Canada, 2013.

Pomeroy, J. W., de Boer, D., and Martz, L. M.: Hydrology and Water Resources of Saskatchewan, University of Saskatchewan Centre for Hydrology Report \#1, University of Saskatchewan, Saskatoon, SK, Canada, 2005.

Pomeroy, J. W., Fang, X., and Williams, B.: Impacts of Climate Change on Saskatchewan's Water Resources, University of Saskatchewan Centre for Hydrology Report \#6, University of Saskatchewan, Saskatoon, SK, Canada, 2009.

Prairie Provinces Water Board: 1969 Master Agreement on Apportionment, available at: http://www.ppwb.ca/information/79/ index.html (last access: 29 January 2014), 2009. 
Quay, R.: Anticipatory governance: A tool for climate change adaptation, J. Am. Plann. Assoc., 76, 496-511, 2010.

Reece, W. and Matthews, L.: Evidence and uncertainty in subjective prediction: Influences on optimistic judgment, Psychol. Rep., 72, 435-439, 1993.

Saskatchewan Ministry of Agriculture: Irrigation: Lake Diefenbaker's Unfinished Business, available at: http://www.agriculture.gov.sk.ca/Default.aspx?DN= 227d43cb-139d-418d-a6a8-45d3bd02ce0e (last access: 12 March 2013), 2012.

Saskatchewan Water Security Agency: 25 Year Saskatchewan Water Security Plan, available at: https://www.wsask.ca/Global/ About\%20WSA/25\%20Year\%20Water\%20Security\%20Plan/ WSA_25YearReportweb.pdf (last access: 7 April 2014), 2013.

Saskatchewan Water Security Agency: Dams and Reservoirs: Lake Diefenbaker, available at: http://www.swa. $\mathrm{ca} /$ WaterManagement/DamsAndReservoirs.asp?type= LakeDiefenbaker, last access: 7 April 2014.

Schindler, D. and Donahue, W.: An impending water crisis in Canada's western prairie provinces, P. Natl. Acad. Sci. USA., 103, 7210-7216, 2006.

Sivapalan, M., Savenije, H. H. G., and Blöschl, G.: Sociohydrology: A new science of people and water, Hydrol. Process., 26, 1270-1276, doi:10.1002/hyp.8426, 2012.

Statistics Canada: Population and dwelling counts, for Canada, provinces and territories, 2011 and 2006 censuses, available at: http://www12.statcan.gc.ca/census-recensement/2011/dp-pd/ hlt-fst/pd-pl/Table-Tableau.cfm?LANG=Eng\&T=101\&S= 50\&O=A (last access, 11 April 2013), 2013.
The Economist: Alberta's floods: A changing tide?, http://www. economist.com/blogs/americasview/2013/06/alberta-s-floods (last access: 18 November 2013), 26 June 2013.

Timmer, D. K., de Loe, R. C., and Kreutzwider, R. D.: Source water protection in the Annapolis Valley, Nova Scotia: Lessons for building local capacity, Land Use Policy, 24, 187-198, 2007.

Toth, B., Corkal, D. R., Sauchyn, D., van der Kamp, G., and Pietroniro, E.: The Natural Characteristics of the South Saskatchewan River Basin: Climate, Geography and Hydrology, in: A Dry Oasis: Institutional Adaptation to Climate on the Canadian Plains, edited by: Marchildon, G. P., Canadian Plains Research Center Press, Regina, Saskatchewan, Canada, 95-127, 2009.

Wandal, J., Young, G. and Smit, B.: The 2001-2002 drought: Vulnerability and adaptation in Alberta's special areas, in: A Dry Oasis: Institutional Adaptation to Climate on the Canadian Plains, edited by: Marchildon, G. P., Canadian Plains Research Center Press, Regina, SK, Canada, 211-234, 2009.

Wheater, H. S.: Progress in and prospects for fluvial flood modeling, Philos. T. Roy. Soc. A., 360, 1409-1431, 2002.

Wheater, H. S.: Water management for a changing climate; challenges and opportunities, Proceedings of the 18th Convocation of the International Council of Academies of Engineering and Technological Sciences (CAETS2009), Calgary, Canada, 317 July 2009.

Wheaton, E., Kulshreshtha, S., Wittrock, V., and Koshida, G.: Dry times: hard lessons from the Canadian drought of 2001 and 2002, Can. Geogr., 52, 241-262, 2008.

Wilby, R. L. and Dessai, S.: Robust adaptation to climate change, Weather, 65, 180-185, 2010. 